\title{
Competency-Based Training in Hydrological Education
}

\author{
Larisa Timofeeva \\ Russian State Hydrometeorological \\ University \\ Saint Petersburg, Russia \\ tilarisa@gmail.com
}

\author{
Zinaida Timofeeva \\ Peter the Great St.Petersburg \\ Polytechnic University \\ Saint Petersburg, Russia \\ whoiszoe@gmail.com
}

\begin{abstract}
Hydrology is an interdisciplinary science, incorporating aspects of many Earth Sciences. Key hydrological tasks such as floods prediction, quantitative and qualitative assessment of water resources and the environmental status of water bodies become increasingly important and challenging. Latest advances in scientific and technological developments require update training. The World Meteorological Organization (WMO) encourages increasing capacity of its Training Centres to address the rapidly developing demand for improved services. However, adequate education is generally not yet available. Implementation of competency-based training is needed, including active learning approaches. The paper presents international experiences and results of the use of projectbased and flipped learning while teaching hydrological curriculum at Russian State Hydrometeorological University, Saint Petersburg. Some pros and cons of these approaches and difficulties of their implementation are discussed. Usually, students improve both their competence to work independently and solve problems collaboratively. Tackling near real issues and dealing with case studies get them more engaged in educational process and enhance practical outcomes. The feedback from the students and exam results have proved the efficiency of these approaches.
\end{abstract}

Keywords-competency, flipped classrooms, hydrology, project.

\section{INTRODUCTION}

Competency-based training (CBT) focuses on learners' practical achievements. In the late 1990 s, the use of new techniques and data in hydrometeorology caused an increasing demand for more practical training outcomes. The CBT era started. Such approach is encouraged by the World Meteorological Organization (WMO) and applied in its 28 Regional Training Centers, according to Competency Requirements for Education and Training Providers [1]. Russian State Hydrometeorological University (RSHU) has been one of them since 1994.

Hydrological curriculum has been taught at RSHU since 1930s and great experiences were gained. However, the content of former five-year Engineering Programmes, even dramatically compressed, can't be included in fouryear Bachelor Programmes. They stay lecture-based, don't guarantee practical outcomes and are abundant with out of date content, which doesn't correspond to the students' professional future. Unfortunately, trainers often teach students in a traditional face-to-face lecture style, nearly the same way they were taught and are most familiar with. However, this strategy is not the most effective for engaging students. Recent research has shown a potential for great variability within the hydrological curriculum [2]. Implementing active-learning approaches based on available open resources trainers can serve as more of a "coach" or "mentor" to the students. Teaching this way requires fulfilling modern competencies.

According to [2], personnel should be competent to: (1) Identify learning needs and specify learning outcomes; (2) Determine a learning solution; (3) Design learning activities and produce learning resources; (4) Deliver training and manage the learning experience; (5) Assess learning and evaluate the training process.

The WMO supports building training capacity through courses and workshops delivering by the Education and Training Office (ETR) on- and offline. The WMO Global Campus concept encourages individuals and institutions to move away from considering only what they can develop or deliver themselves to how they can benefit from or contribute to the wider WMO ETR community. Useful resources are available at the Training Portal in the WMO web-site [3]. There are resources on active learning strategies, used within the CBT framework.

Project-based learning (PBL) and Flipped Learning (FL) have become quite popular in engineering education, since they allow more than just gaining required professional competencies, which are likely changing during the professional development of an individual. These approaches benefit the ability to learn and develop continuously (lifelong learning), to work in teams and to be able to integrate between sciences studied at University.

\section{Materials AND METHODS}

At RSHU, Basic Hydrology is taught for two semesters to the second and third year students. The number of them in a group vary from 15 up to nearly 30 . There is one lecture and one practical class a week.

Traditionally, the content is presented topic by topic. Such format does not always demonstrate how the course 
topics fit together as a whole and how they can be used to solve real professional problems and help obtain practical outcomes from the Course.

Since the course is completed with an exam and a course project, it was decided to start preparing the students for such challenges during the first semester. For the last two years, $\mathrm{FCl}$ and $\mathrm{PBL}$ were applied to develop deep content knowledge as well as critical thinking, creativity, and skills communication, e q professionals skills, which can make current students more competitive at job market.

\section{A. Flipped Classrooms}

The simplest definition of a Flipped Classrooms approach is expressed as "what is done at school done at home, homework done at home completed in class". This approach was introduced in the 1990s by Harvard Professor Eric Mazur, but came into general use in the early mid-2000s when it was popularized by chemistry teachers Jon Bergman and Aaron Sams [4] and the founder of the Khan Academy, Salman Khan. In FL, part or all of direct instruction is delivered through videos and other media; and the class time is used for engaging students in collaborative, hands-on activities [5]. The traditional FCl model is presented in Fig. 1.

As seen in Fig. 1, FCl training needs changes in content, teacher's role and delivery mode.

It should be noted, that reading and studying the theory before class is not a novelty, but it used to be more popular while teaching humanitarian disciplines. The terms Flipped Classrooms and Flipped Learning are not interchangeable. $\mathrm{FCl}$ does not necessarily lead to blended FL, which requires full incorporating of the following four pillars: flexible environment, learning culture, intentional content, professional educator [7].

Since the entire Basic Hydrology course has not been flipped yet, we can only talk about $\mathrm{FCl}$. The topics, taught during the first semester, are all about rivers and processes on their catchments. Studying some of them requires solid theoretical basis, so they are particularly suitable for $\mathrm{FCl}$. Successful implementation of $\mathrm{FCl}$ in engineering education requires relevant resources available (including online ones), which were rather limited recently. Unfortunately, due to the lack of such resources in Russian only few topics can be taught as $\mathrm{FCl}$.

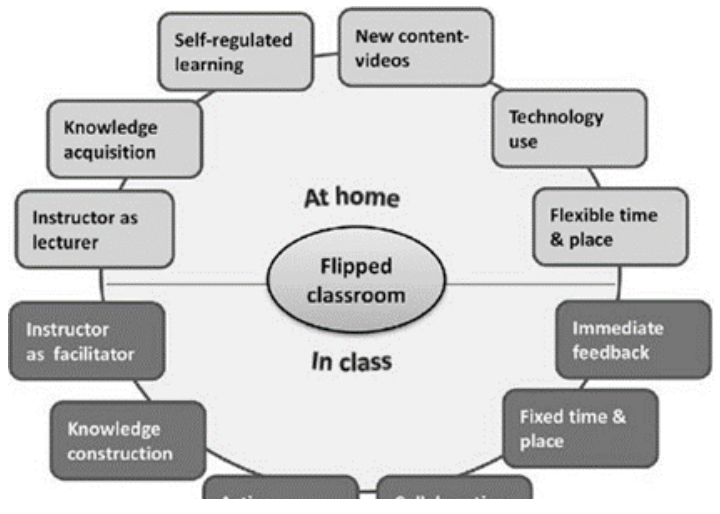

Fig. 1. The components of the traditional flipped classroom model [6].
Snowmelt processes, the most complex topic, was chosen for the experiment, since understanding the physical nature of snowmelt and methods for its intensity calculation is time consuming and needs advanced preparation. Luckily, in 2011, the authors were introduced to the Community Outreach Missions Education Team/ University Corporation for Atmospheric Research (COMET/UCAR) program, which offers e-lessons and courses on Earth Sciences. Some lessons were translated into Russian and are used for teaching at RSHU. Original lessons are available on the web-site [8]. After completing the Snowmelt Processes lesson, students have an on-line Quiz and the results are sent to the teacher automatically. Passing the Quiz is a kind of a formative assessment, which is often neglected, but should not be, since a proper assessment enhances learning, and lack of assessment weakens training process. Assessment can be carried out via MOODLE.

Besides completing the e-lesson, later on students are asked to explore the data base, available on the web-site of the World Data Center of Roshydromet (www.meteo.ru), and try to get the data necessary for carrying out further snowmelt intensity calculations.

Thus, such pre-lesson activities save time for a more detailed discussion of the process being studied and dealing with possible difficulties of data access and calculations. Thankful to applying FCL, it has become possible to complete this practical work in a near real mode. Earlier, this work, due to being extremely time and efforts consuming, was done in a simplified form, based on the data and templates, prepared by trainers. This couldn't make students more competent in their future profession. Obviously, applying blended flipped classrooms has resulted not only in deeper theoretical understanding (Comet lessons, video resources and other media), but in important practical outcomes: students become more prepared for independent professional activities (use of data bases, technical means, ability to communicate). FCL can be considered as a powerful CBT approach, which can alter even Bloom's Taxonomy (Fig. 2). Thus, the trainers' role changes from being a main information source (lower Taxonomy levels) to coaching the students while working together on analyzing and evaluating of the training content (upper Taxonomy levels).

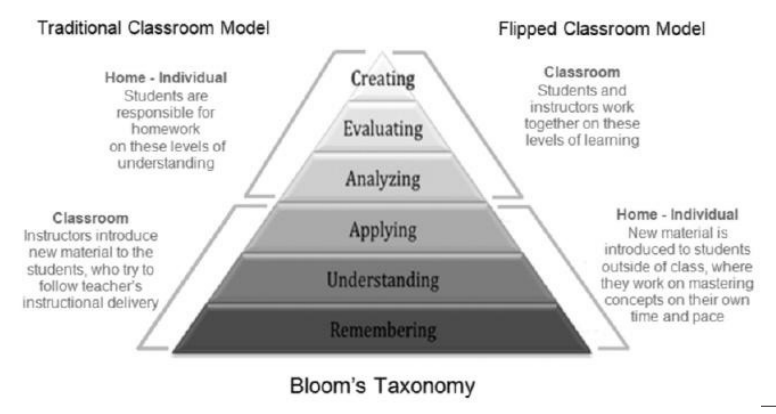

Fig. 2. Connection between Traditional and Flipped Classroom to Bloom's Taxonomy [9]. 


\section{B. Project-based training}

Educators agree that students learn better, when they engage in complex problems and projects [10]. So, if there is a project planned in the Course, it is wise to make the best of it! If a project is not included, a trainer can turn one or several practical works into small projects.

While teaching Practical Basic Hydrology different ways are used. During the first semester, three practical works are combined into a small project (P1), during the second semester there is a planned project (P2). In both cases, students work on authentic, meaningful projects for several weeks. It allows self-pacing and more time for sorting out real problems or answering complex questions. In our case, intended outcomes from both P1 and P2 were enhanced competencies to collect, analyze and apply data for solving hydrological tasks.

P1 consists of three practical works (including flipped Snowmelt Processes, described above), which are carried out for a selected river and for a particular year. Thus, younger students work on the same tasks but with different objects (data). They have to learn how to collect hourly, daily, monthly and annual data on a number of hydrometeorological parameters from traditional (Monthly weather reviews) and modern (e-databases) sources. The experiences gained will make them competent data users. Additionally, application the data for studying water regime and catchment processes (analytically and graphically) ensure students' deeper hydrological understanding. When students collect all the three works together and analyze them, they can realize how melting water forms high flow and rains become runoff. This might be their first professional finding! Besides, such collection of small projects might start a further research.

Having successfully completed P1, students are positively aimed towards more complex P2. For years, course projects on hydrology were typical and covered only a few topics. Such situation was explained with data and techlogies limitations. It resulted in lack of original researches: students often tried to copy earlier completed projects with little change. Nowadays, former limitations are easily coped, and working on projects have become a powerful CBT means. The key problem is to choose a project topic, which would engage students and, possible, become a part of their Bachelor thesis. The bulk of the work is done independently, based on the experiences gained earlier, but the trainer's help is needed. At the end, students demonstrate their theoretical achievements and practical skills by developing presentations for their peers, who assess them according to specific rubrics.

It should be noted that carrying out P1 might not be enough to prepare less advanced students for independent P2. If so, it might be useful to complete an additional pre-project, which can be done in small groups of two to four. Thus, the less advanced students are, the more project-based training is required.

As a result, not only intended outcomes are achieved, but students also develop deeper content knowledge as well as critical thinking, creativity, and communication skills. Project based training forms friendly environment among students and teachers.

\section{RESUlTS AND DISCUSSION}

The first author's experiences of applying CBT through Project Based Training and Flipped Classrooms in hydrological education at RSHU have been quite positive. However, there are more evidence on these approaches pros and cons for both, students and trainers.

As for students, it should be taken into account that they learn differently and not all of them accept active learning, which requires to be engaged in the learning activity in order to realize any learning benefit. When they're not engaged or not willing to work at home, those approaches don't work perfectly.

The main benefit for students is enhanced professional competencies and success at exams. Even though the students who were taught through $\mathrm{FCl}$ and PBT don't do better at exams than the students, who were taught traditionally, they are more exposed to further teamwork, leadership and communication skills development. As a surprising benefit, replacing lecturing with in-class work and discussion has become personally rewarding. The variability in student performance has decreased [11], since they could learn from peers, class discussions and trainers' immediate feedback. Except training undergraduate students, individual $\mathrm{FCl}$ seem to be useful while teaching Master students, who often have different background.

As for trainers, there are certain difficulties. First, Competency Requirements for hydrologists are not approved by the WMO yet. So learning outcomes should be thought out thoroughly and discussed with stakeholders, if needed. Second, trainers' competencies include choosing technology and software required for delivering training, preparing presentations and learning resources, applying learning activities that include authentic tasks, build upon the prior knowledge of students. No doubt, that implementing $\mathrm{FCl}$ and PBT leads to additional workload on trainers. So, they need help from University Administrations, experts in pedagogy and colleagues. Obviously, flipping entire courses is possible only if responsible authorities approve and support it. The more flipped classrooms are there, the higher students' learnability and better entire learning outcomes will be.

Luckily, a lot of resources on $\mathrm{FCl}$ and $\mathrm{PBT}$ are available now. Among them are: web-sites, which offer numerous theoretical and practical materials [5], [12], the American Society for Engineering Education [13], specialized resources for the geoscience community provided by The United States Geological Survey [14] and a free collection of numerous training resources, designed by COMET UCAR [8].

\section{Conclusions}

Opportunities in hydrologic science have never been greater, and the challenges that lie ahead have never been more compelling [15]. While there is a rising interest in and demand for civil engineering and hydrology educa- 
tion, some have suggested a widening gap between how students are instructed in hydrology, and the subsequent professional skill set required for a career as a hydrological engineer [16]. According to the WMO requirements, hydrological training should be delivered by competent personnel, be competency based and include modern active learning approaches. Based on the experiences of teaching Basic Hydrology to undergraduate students in RSHU, it is possible to conclude:

1. Flipped-classrooms are easier applied to younger students, since all their stages are fully controlled by teachers and few specific skills are required from the students. They study some theoretical content, prepared by the teacher, in advance. This saves time for mastering practical skills at classes (data bases, Excel, GIS, AutoCAD). There is more time to develop students' competency to work independently.

2. Project-based training better suits older students, since it is a cooperative, rather time and efforts consuming approach. A real on-job environment can be created while solving authentic problems. Students can improve their competency in face-to-face communication and sorting out problems collaboratively to get practical learning outcomes.

The feedback from students and exam results have proved the efficiency of CBT.

\section{REFERENCES}

[1] Competency Requirements for Education and Training Providers. WMO, 2013. [Online]. Available: https://library.wmo.int/ pmb_ged/etrp_competency-requirements_en.pdf, [Accessed Feb. 10, 2019].

[2] T. Wagener, C. Kelleher, M. Weiler, B. McGlynn, M. Gooseff, L. Marshall, T. Meixner, K. McGuire, S. Gregg, P. Sharma, and S. Zappe, "It takes a community to raise a hydrologist: the Modular Curriculum for Hydrologic Advancement (MOCHA)," Hydrol. Earth Syst. Sci., 16, 3405-3418, 2012, [Online]. Available: Hydrology and Earth System Sciences https://www.hydrol-earthsyst-sci.net/16/3405/2012/ [Accessed Mar. 01, 2019], https:// doi:10.5194/hess-16-3405-2012

[3] WMO Education and Training Programme, [Online]. Available: https://etrp.wmo.int/course/index.php?categoryid=49 [Accessed Mar. 01, 2019].

[4] J. Bergmann and A. Sams, "Flip Your Classroom: Reach Every Student in Every Class Every Day", Washington DC: International Society for Technology in Education, pp. 120-190, 2012.
[5] FLIP Learning, [Online]. Available: https://flippedlearning.org/ board/ [Accessed Feb. 21, 2019].

[6] I. Blau and T. Shamir-Inbal, "Re-designed flipped learning model in an academic course: The role of co-creation and co-regulation", Journal Computers \& Education archive, vol. 115, Issue C, pp. 69-81, Dec. 2017. [Online]. Available: https://www.researchgate. net/publication/318831616_Re-designed_flipped_learning_model in an academic course The role of co-creation and co-regulation [Accessed Feb. 21, 2019], DOI: 10.1016/j.compedu.2017.07.014.

[7] The Four Pillars of F-L-I-P, 2014. Flipped Learning Network.

[Online]. Available: https://flippedlearning.org/wp-content/uploads/2016/07/FLIP handout FNL_Web.pdf [Accessed Feb. 20, 2019].

[8] COMET MetED, [Online]. Available: https://www.meted.ucar. edu/index.php [Accessed Feb. 21, 2019].

[9] A.P. Lopes and F. Soares, Flipping a mathematics course, a blended learning approach. 12th International Technology, Education and Development Conference INTED2018, Mar. 5-7, 2018, Valencia, Spain. [Online]. Available:

https://www.researchgate.net/publication/323900654_FLIPPING_A_MATHEMATICS_COURSE_A_BLENDED_LEARNING APPROACH, [Accessed Feb. 15, 2019]. DOI: 10.21125/ inted.2018.0749.

[10] T. Wagener, M. Weiler, B. McGlynn, L. Marshall, M. McHale, T. Meixner and K. McGuire, "Taking the pulse of hydrology education”, Hydrol. Proc., 21, 1789-1792, 2007. [Online]. Available: https://onlinelibrary.wiley.com/doi/abs/10.1002/hyp.6766, [Accessed Feb. 20, 2019]. https://doi.org/10.1002/hyp.6766

[11] S. C. Shah-Fairbank and K. Lamb, Comparison of traditional, hybrid and flipped classrooms for water resources design courses: American Society for Engineering Education, Pacific Southwest Section Meeting, April, 2017, Tempe, Arizona. [Online]. Available: https://peer.asee.org/29209, [Accessed Feb. 25, 2019].

[12] Buck Institute for Education PBLWORKS. [Online]. Available: https://www.pblworks.org/, [Accessed Feb. 20, 2019].

[13] American Society for Engineering Education. [Online]. Available: https://www.asee.org/, [Accessed Feb. 15, 2019].

[14] U.S. Geological Survey. [Online]. Available: https://www.usgs. gov/, [Accessed Feb. 15, 2019].

[15] W. J. Gutowski Jr., G. M. Hornberger, E. Bernhardt, W. E. Dietrich, D. Entekhabi, G. E. Fogg, E. Foufoula-Georgiou, W. B. Lyons, K. W. Potter, S. W. Tyler, H. J. Vaux, C. J. Vorosmarty, C. Welty, C. A. Woodhouse and C. Zheng, "Challenges and Opportunities in the Hydrologic Sciences". Geological and Atmospheric Sciences Reports, 4, 2012. [Online]. Available: https://lib. dr.iastate.edu/ge_at_reports/4, [Accessed Feb. 21, 2019].

[16] M.M. Lombardi, "Authentic Learning for the 21st Century: An Overview", ELI Paper 1, 2007. https://www.researchgate.net/ publication/220040581_Authentic_Learning_for the_21st_Century_An_Overview, [Accessed Feb. 16, 2019]. 